\title{
Pendidikan Dini Mitigasi Bencana
}

\author{
Muhammad Eko Atmojo \\ Program Studi Ilmu Pemerintahan, Fakultas Ilmu Sosial dan Ilmu Politik, \\ Universitas Muhammadiyah Yogyakarta, atmojoeko91@gmail.com
}

\begin{abstract}
Abstrak
Pendidikan dini mitigasi bencana merupakan hal yang sangat penting bagi masyarakat Indonesia, hal ini dikarenakan Indonesia berada di daerah cicin api. Dengan kondisi geografis Indonesia yang berada di daerah cicin api maka akan banyak sekali potensi bencana yang muncul diantaranya gempa bumi, tsunami, gunung merapi meletus, tanah longsor, banjir, putting beliung dan lain-lain. Maka dari itu pendidikan dini mitigasi bencana bagi masyarakat dan akan-anak usia dini merupakan hal yang paling penting, sehingga ketika terjadi bencana masyarakat dan anak-anak sudah memahami langkah awal untuk penyelamatan diri. Metode yang digunakan dalam kegiatan ini adalah forum group discussion, sosialisasi dan simulasi mitigasi bencana. Pada kegiatan pengabdian masyarakat ini diikuti oleh guru dan siswa dengan sangat antusias, selain itu dengan adanya kegiatan ini banyak manfaat yang didapatkan oleh guru dan siswa-siswi SD Negeri Bantul Timur. Pada pelaksanaan forum group discussion banyak sekali guru yang belum memahami mitigasi bencana sehingga kegiatan ini menambah wawasan dan pengetahuan guru. Selain itu guru juga baru mengetahui bahwa ketika terjadi bencana maka orang dewasa mempunyai tanggungjawab yang sangat besar. Kegaitan sosialisasi dan simulasi juga diikuti dengan sangat antusias, serta kegiatan ini menambah pengetahuan serta wawasan bagi siswa dan guru SD Negeri Bantul Timur. Pada kegaitan simulasi ini ada beberapa tipe penyelamatan yang dilakukan diantaranya ketika terjadi bencana gempa bumi yang mengakibatkan kebakaran.
\end{abstract}

Kata Kunci: Cincin Api, Pendidikan Dini, dan Mitigasi Bencana

\begin{abstract}
Early education of disaster mitigation is crucial for Indonesian people, it is because Indonesia is in the area of the ring of fire. With the geographical condition of Indonesia in the area of the ring of fire, there will be many potential disasters that arise, including earthquakes, tsunami, Mount Merapi erupting, landslides, flooding, putting Pickaxe and others. Therefore, early education disaster mitigation for the community and early childhood is an essential thing, so when a community disaster occurs and the children already understand the initial step for self-rescue. The methods used in this activity are the Group discussion forum, socialization and disaster mitigation simulation. In the event of community devotion followed by teachers and students with a very enthusiastic, in addition to this activity many benefits gained by teachers and students of East Bantul State Elementary School. In the implementation of a
\end{abstract}


group discussion forum many teachers who have not understood disaster mitigation so that this activity adds insight and knowledge of teachers. Besides, the teacher also recently learned that when there is a disaster, the adults have a huge responsibility. Socialization and simulation are also followed by very enthusiastic, and this activity adds knowledge and insight to the students and teachers of East Bantul State Elementary School. In this simulation, several types of rescue occur during the earthquake disaster that caused a fire.

Keywords : Ring of Fire, Pendidikan Dini, dan Mitigasi Bencana

\section{Pendahuluan}

Pendidikan merupakan salah satu pokok terpenting dalam kehidupan manusia serta berbangsa maupun bernegara. Dengan adanya pendidikan maka akan banyak mempunyai pengetahuan dan pengalaman. Salah satu pokok terpenting lainnya adalah pendidikan mitigasi bencana, mengingat Negara Kesatuan Republik Indonesia merupakan salah satu Negara yang mempunyai banyak potensi bencana baik dari gempa bumi, tsunami, gunung berapi, banjir, kebakaran, tanah longsor dan lain sebagainya. Dengan banyaknya potensi bencana yang dimiliki oleh Negara Indonesia maka pendidikan dini mitigasi bencana sangat penting untuk diberikan kepada masyarakat umumnya dan khususnya kepada anak-anak. Sehingga ketika terjadi bencana masyarakat dan anak-anak sudah bisa melakukan penyelamatan diri, dengan begitu akan sangat membantu sekali dalam hal mengurangi korban jiwa.

Dengan kondisi Negara yang berada di atas cicin api atau ring of fire maka sangat wajar sekali jika Indonesia medapatkan label sebagai Negara yang snagat rawan akan bencana. Hal ini dapat dibuktikan dengan berbagai bencana yang terjadi di Indonesia. Dari predikat tersebut dalam sepuluh tahun terakhir ditandai dengan bencana gempa dan tsunami Aceh (2004), gempa Yogyakarta (2006), Tasikmalaya (2009), Sumatra Barat (2010), gempa dan tsunami Mentawai (2010), tanah longsor Wassior di Papua Barat (2010) dan letusan Gunung Merapi Yogyakarta (2010) yang membawa korban ratusan jiwa dan ratusan triliun rupiah dalam nilai ekonomi. Letusan Gunung Merapi yang tak kunjung reda, makin mempertegas predikat NKRI sebagai negara sabuk api (Suharjo, 2015 dalam Suamirka, 2017). Selain itu berdasarkan catatan Badan Nasional Penanggulangan Bencana (BNPB), selama 2018, kejadian bencana di Indonesia mencapai angka 2.426 kali. Adapun jumlah korbannya mencapai 4.231 orang jiwa dan 6.948 orang. Angka tersebut tercatat hingga 18 Desember 2018 dan tidak termasuk bencana tsunami di Selat Sunda, longsor di Sukabumi, dan puting beliung di Cirebon yang terjadi setelah 18 Desember (https:// www.republika.co.id).

Dari berbagai macam potensi bencana yang ada hanya ada satu potensi bencana yang mempunyai potensi sangat besar ialah gempa bumi. Indonesia merupakan salah satu Negara yang sangat rawan akan bencana gempa bumi. Menurut U.S 
Geological Survey (USGS), 80\% gempa bumi terbesar di dunia terjadi di sepanjang cincin api pasifik. Cincin Api pasifik ini memiliki zona rekahannya yang panjang membentang dari mulai Chile, Jepang hingga Asia Tenggara, termasuk Indonesia. Kondisi rekahan cincin api pasifik ini lah yang menyebabkan di Indonesia sering mengalami gempa bumi (https://www.kompasiana.com). Dengan kondisi seperti ini maka masyarakat Indonesia harus siaga dalam menghadapi bencana karena bencana gempa bumi bisa terjadi sewaktu-waktu. Oleh karena itu sangat penting sekali pendidikan mitigasi bencana dilakukan sejak usia dini. Menurut Rahmat (2006) dalam Nirmalawati (2011) mitigasi adalah suatu tahapan yang bertujuan untuk mengurangi kemungkinan dampak negatif kejadian bencana terhadap kehidupan atau dapat diartikan bahwa mitigasi sebagai mengambil tindakan-tindakan untuk mengurangi pengaruh-pengaruh dari suatu bahaya sebelum bahaya terjadi. Sedangkan untuk bencana sendiri adalah keadaan yang mengganggu kehidupan sosial ekonomi masyarakat yang disebabkan oleh gejala alam atau perbuatan manusia (Nirmalawati, 2014).

Di Indonesia hampir semua daerah mempunyai potensi bencana baik bencana dalam skala kecil maupun bencana dalam skala besar. Salah satu daerah yang mempunyai potensi bencana adalah Daerah Istimewa Yogyakarta, dimana Yogyakarta mempunyai banyak potensi bencana salah satunya adalah Gunung Berapi, Gempa Bumi dan lain sebagainya. Hal ini karena didukung dengan kondisi geografis Provinsi Daerah Istimewa Yogyakarta yang berada di daerah selatan Pulau Jawa dan berada di atas ring of fire. Dengan keadaan geografis seperti ini maka pemerintah harus mempunyai inisiatif untuk memberikan pendidikan dini mitigasi bencana bagi masyarakat. Dengan adanya inisiatif tersebut akan sangat bermanfaat dan menambah pengetahuan bagi masyarakat Yogyakarta. Selain masyarakat unsur lain yang perlu diperhatikan adalah anak-anak usia dini, dengan kondisi geografis yang rawan akan bencana maka anak-anak usia dini harus mulai dikenalkan tentang mitigasi bencana. Sehingga dengan dikenalkannya mitigasi bencana sejak usia dini akan sangat bermanfaat bagi anak-anak, terutama jika terjadi bencana mereka sudah memahami apa yang harus dilakukan.

Adanya pengenalam mitigasi bencana sejak dini juga harus dilakukan lewat pendidikan terutama di sekolah, akan lebih bagus lagi jika dimasukkan ke dalam kurikulum pendidikan di tingkat dasar sampai dengan menengah atas. Menurut Suarmika (2017) pendidikan menjadi salah satu sarana yang efektif untuk mengurangi risiko bencana dengan memasukkan materi pelajaran tentang bencana alam sebagai pelajaran wajib bagi setiap siswa di semua tingkatan, terutama di sekolah-sekolah yang berada di wilayah risiko bencana. Kurikulum yang berbasis kearifan lokal, diharapkan dapat diterima dan dapat dengan mudah di pahami oleh siswa. Dengan adanya pendidikan mitigasi bencana di dalam sekolah akan sangat 
membantu Negara dalam hal mitigasi bencana, mengingat Indonesia merupakan Negara yang rawan akan bencana. Berdasarkan permasalahan yang ada maka sangatlah penting jika kegiatan pengabdian masyarakat ini dilakukan di sekolahsekolah dasar di Kabupaten Bantul, mengingat Kabupaten Bantul merupakan daerah yang rawan akan bencana alam dan berada di daerah pesisir. Selain itu kegiatan ini juga bisa membantu BPBD Kabupaten Bantul dalam mewujudkan Sekolah Aman Bencana.

\section{Metode}

Demi mendapatkan hasil yang maksimal maka pengabdian masyarakat PKM dengan tema Pendidikan Dini Mitigasi Bencana ini menggunakan beberapa metode salah satunya adalah sebagai berikut:

1. Forum group discussion salah satu metode yang kami gunakan, dengan adanya metode ini kami berharap mendapatkan informasi serta wahana berbagi pengetahuan mengenai mitigasi bencana. Sasaran dari kegiatan forum group discussion ini adalah semua guru Sekolah Dasar Negeri Bantul Timur, penjaga sekolah serta satpam. Sehingga dengan adanya kegaitan ini guru, penjaga sekolah maupun satpam bisa lebih memahami tanggungjawab dan tugas mereka jika terjadi bencana di sekolah.

2. Sosialisasi ini merupakan salah satu komponen paling penting untuk mengaplikasikan ilmu yang didapat. Sasaran dari kegiatan sosialisasi ini diutamakan kepada siswa-siswi sekolah serta guru, penjaga sekolah maupun satpam. Dengan adanya kegaitan ini siswa, guru, penjaga sekolah maupun satpam bisa lebih memahami mengenai apa yang harus dilakukan jika terjadi bencana di sekolah baik bencana gempa bumi maupun kebakaran.

3. Simulasi merupakan rangkaian kegiatan yang paling penting, terutama untuk mengedukasi siswa dan guru. Simulasi dimulai dari dalam kelas dengan seting seolah-olah masih ada kegiatan belajar mengajar, sehingga guru maupun siswa bisa memahami apa yang harus dilakukan jika terjadi bencana seperti gempa bumi, dan kebakaran pada saat kegiatan belajar mengajar.

\section{Hasil dan Pembahasan}

\section{a. Forum Group Discussion (FGD)}

Indonesia merupakan salah satu Negara yang sangat rawan bencana, mengingat kondisi geografis Indonesia yang terletak di antara lempeng bumi. Dengan keadaan geografis semacam itu maka perlu pelaksanaan pendidikan dini mitigasi bencana terhadap masyarakat umumnya dan kepada anak-anak di usia dini. Dengan adanya pendidikan dini terhadap masyarakat maka akan sangat membantu sekali ketika ada bencana yang terjadi. Oleh karena itu pendidikan dini mitigasi bencana memang sangat perlu dilakukan dan akan sangat bagus sekali jika pendidikan dini mitigasi 
bencana di masukkan kedalam kurikulum pendidikan. Mengingat sampai hari ini masih banyak sekali sector pendidikan yang belum memasukkan pendidikan dini mitigasi bencana ke dalam bagian dari kurikulum atau pendidikan.

Dengan kondisi Negara yang rawan akan bencana maka sangat perlu sekali pendidikan dini mitigasi bencana dilaksanakan kepada sekolah atau sector pendidikan. Mengingat banyaknya anak Indonesia yang setiap harinya berada di sekolah serta banyaknya jumlah anak Indonesia yang melajutkan pendidikan dimulai dari sector taman kanak-kanak sampai dengan perguruan tinggi. Dengan begitu maka pendidikan dini mitigasi bencana sangat diperlukan sekali di bidang pendidikan atau sector pendidikan, mengingat orang yang bertanggung jawab ketika ada bencana adalah orang dewasa, sehingga bapak/ibu guru juga mempunyai tanggung jawab yang sangat besar terhadap keselamatan anak-anak ketika terjadi bencana di sekolah.

Dalam pelaksanaan pengabdian masyarakat dengan tema pendidikan dini mitigasi bencana yang dilakukan di SD Negeri Bantul Timur menggunakan beberapa metode diantaranya adalah forum group discussion, sosialisasi kepada siswa mengenai penyelamatan diri serta simulasi mitigasi bencana. Kegiatan forum group discussion diikuti oleh guru kelas, guru olahraga, maupun penjaga sekolah. Dengan adanya kegaitan ini guru-guru di SD Negeri Bantul Timur mendapatkan banyak pengetahuan dan pelajaran diantaranya adalah pengetahuan tentang mitigasi bencana. Mengingat SD Negeri Bantul Timur merupakan sekolah yang belum pernah mendapatkan sosialisasi mitigasi bencana, sehingga kegiatan forum group discussion ini sangat bermanfaat sekali. Selain itu guru-guru yang ada di sekolah tersebut juga bisa memahami bahwasannya tanggung jawab seorang guru bukan hanya mengajar saja melainkan ada tanggungjawab lainnya seperti keselamatan anak-anak didik jika terjadi bencana di sekolah.

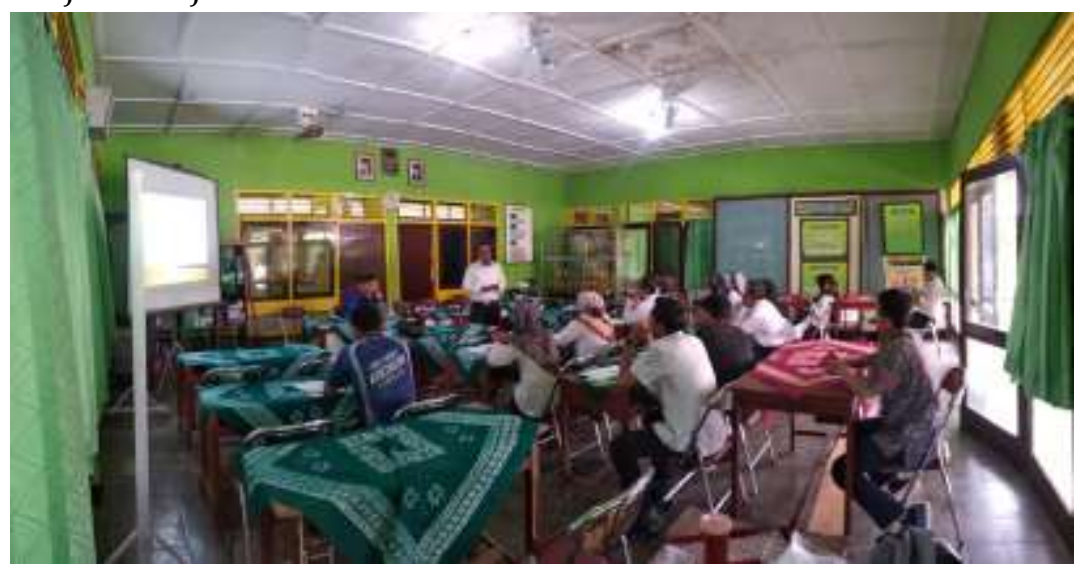

Gambar 1. Kegiatan Forum Group Discussion

Forum group discussion yang telah dilakukan sangat membantu sekali bagi bapak ibu guru dalam menambah wawasan mitigasi bencana. Mengingat Kabupaten Bantul 
merupakan salah satu kabupaten yang rawan bencana, sehingga perlu sekali pendidikan dini mitigasi bencana dilakukan serta disosialisasikan kepada masyarakat. Selain itu dengan adanya kegiatan ini pihak sekolah juga sangat terbantu sekali, terutama dalam mengevaluasi kesiapan sumber daya manusia dan infrastruktur sekolah. Selain itu bapak ibu guru juga sangat terbantu sekali dengan adanya workshop ini, mengingat sampai saat ini belum ada mata pelajaran atau muata local yang membahas tentang pendidikan dini mitigasi bencana. Dengan adanya FGD tersebut maka guru sebagai orang dewasa bisa memahami tanggunjawabnya selain mengajar sehingga jika suatu saat tejadi bencana maka pihak sekolah sudah lebih siap.

\section{b. Sosialisasi dan Simulasi Mitigasi Bencana bagi Siswa}

Selain forum group discussion yang telah dilakukan dengan guru-guru maka langkah atau metode selanjutnya adalah sosialisasi kepada siswa-siswi mengenai pendidikan dini mitigasi bencana. Hal ini sangat penting sekali karena sasaran dari pengabdian masyarakat ini adalah guru dan siswa. Tujuan dari sosialisasi kepada siswa adalah untuk memberi pemahaman dan pengetahuan mengenai mitigasi bencana, mengingat Kabupaten Bantul merupakan salah satu daerah yang sangat rawan bencana seperti gempa bumi. Maka dari itu sosialisasi ini sangat penting sekali dilakukan kepada siswa-siswi Sekolah Dasar Negeri Bantul Timur.

Selain untuk mendukung dan menambah pengetahuan kepada siswa dan guru pendidikan dini mitigasi bencana ini syogyanya sudah mulai diterapkan di sekolahsekolah yang masuk kategori rawan bencana. Akan tetapi sampai saat ini belum ada kurikulum khusus yang mengatur mengenai pendidikan dini mitigasi bencana di sekolah, sehingga masih banyak sekali siswa dan guru yang belum memahamai mitigasi bencana. Hal ini sangat berbahaya bagi guru dan sisiwa jika sewaktu-waktu terjadi bencana seperti gempa bumi, kebakaran dan lain-lain. Oleh karena itu guru sebagai orang dewasa yang berada di sekolah harus memahami mitigasi bencana, sehingga ketika terjadi bencana guru mempunyai tanggungjawab yang sangat besar.

Dengan keadaan geografis Negara yang berada di atas ring of fire, seharusnya pemerintah memasukkan pendidikan dini mitigasi bencana ke dalam kurikulum pembelajaran. Sehingga guru dan siswa bisa memhami apa yang harus dilakukan jika terjadi bencana alam seperti gempa bumi, tsunami dan kebakaran. Pengetahuan dasar mitigasi bencana merupakan hal yang snagat penting sekali diketahui oleh guru dan siswa serta masyarakat Indonesia. Dengan adanya pendidikan dini tersebut akan sangat bermanfaat sekali untuk meminimalisir korban jiwa jika terjadi bencana. Hal ini merupakan hal penting sekali yang harus dilakukan oleh pemerintah selaku pengambil kebijakan, dengan adanya kebijakan penerapan 
kurikulum pendidikan dini mitigasi di sekolah akan sangat berguna dan bermanfaa bagi guru dan siswa.

Dengan belum adanya kurikulum mengenai mitigasi bencana maka ada beberapa hal yang bisa dilakukan oleh sekolah diantaranya adalah sosialisasi kepada siswasiswi dan guru. Dengan adanya sosialisasi ini akan sangat bermanfaat dan menambah wawasan serta pengalaman bagi guru dan sisiwa. Hal ini merupakan salah satu cara atau metode pembekalan kepada siswa dan guru dalam hal mitigasi bencana. Dengan adanya sosialisasi maka siswa dan guru akan bisa lebih siaga dalam pelaksanaan mitigasi bencana.

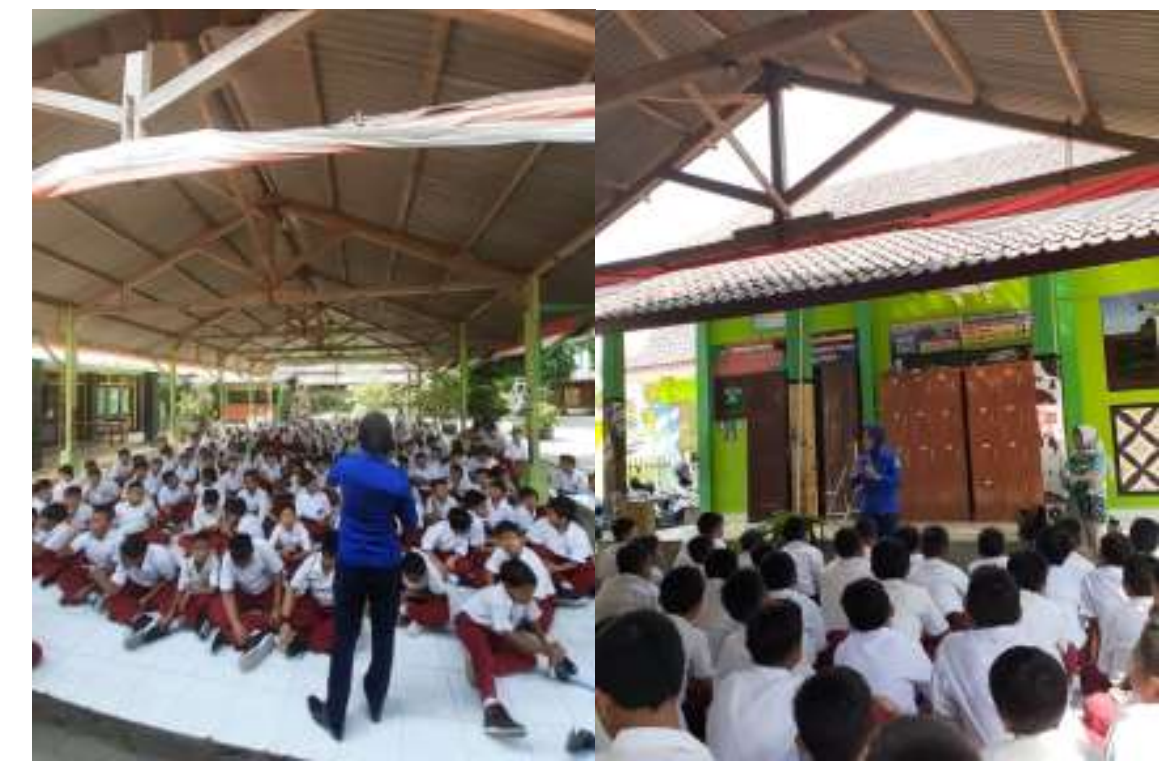

Gambar 2. Kegiatan Sosialisasi Kepada Siswa-Siswi

Kegiatan sosialisasi mitigasi yang dilaksanakan di SD Negeri Bantul Timur diikuti oleh siswa dengan sangat antusias, mengingat hal ini merupakan hal penting sehingga siswa-siswa juga banyak yang tertarik untuk memperhatikan. Dengan adanya acara ini siswa-siswi merasa sangat senang karena mendapatkan pengalaman dan ilmu baru terutama dalam hal mitigasi bencana. Selain itu guru dan kepala sekolah juga merasa sangat senang karena mendapatkan pengalaman dan ilmu baru. Dengan dilaksanakannya sosialisasi ini maka pihak sekolah mempunyai inisiasi menjadikan SD Negeri Bantul Timur sebagai salah satu sekolah aman bencana. Mengingat hal ini sangat penting karena posisi daerah Bantul yang rawan sekali dengan bencana terutama gempa bumi dan tsunami. Selain itu guru dan karyawan juga bisa lebih memahami mengenai tanggung jawab mereka jika sewaktu-waktu terjadi bencana di sekolah. Mengingat ternyata tanggung jawab guru dan karyawan sangat besar jika terjadi bencana di sekolah, oleh karena itu hal ini merasa sangat penting dan bermanfaat bagi guru dan karyawan. 
Kegaitan pengabdian masyarakat ini juga melakukan simulasi terutama simulasi jika terjadi gempa bumi yang mengakibatkan kebakaran. Dengan adanya kegiatan simulasi ini maka guru dan siswa bisa lebih memahami mengenai apa yang harus dilakukan jika terjadi gempa bumi dan kebakaran. Selain itu kegiatan simulasi ini juga baik dilakukan, mengingat SD Negeri Bantul Timur selama ini beum pernah melakukan simulasi mitigasi bencana. Sehingga dengan adanya simulasi ini menjadi salah satu pengetahuan baru bagi siswa-siswi dan guru di SD Negeri Bantul Timur, terutama dalam hal kewaspadaan jika terjadi gempa bumi. Jika terjadi bencana gempa bumi maka siswa dan guru sudah memahami apa yang harus dilakukan untuk menyelematkan diri. Selain itu guru dan siswa juga harus memahami titiktitik evakuasi yang berada di sekolah tersebut, baik evakuasi maupun titik kumpul untuk evakuasi.
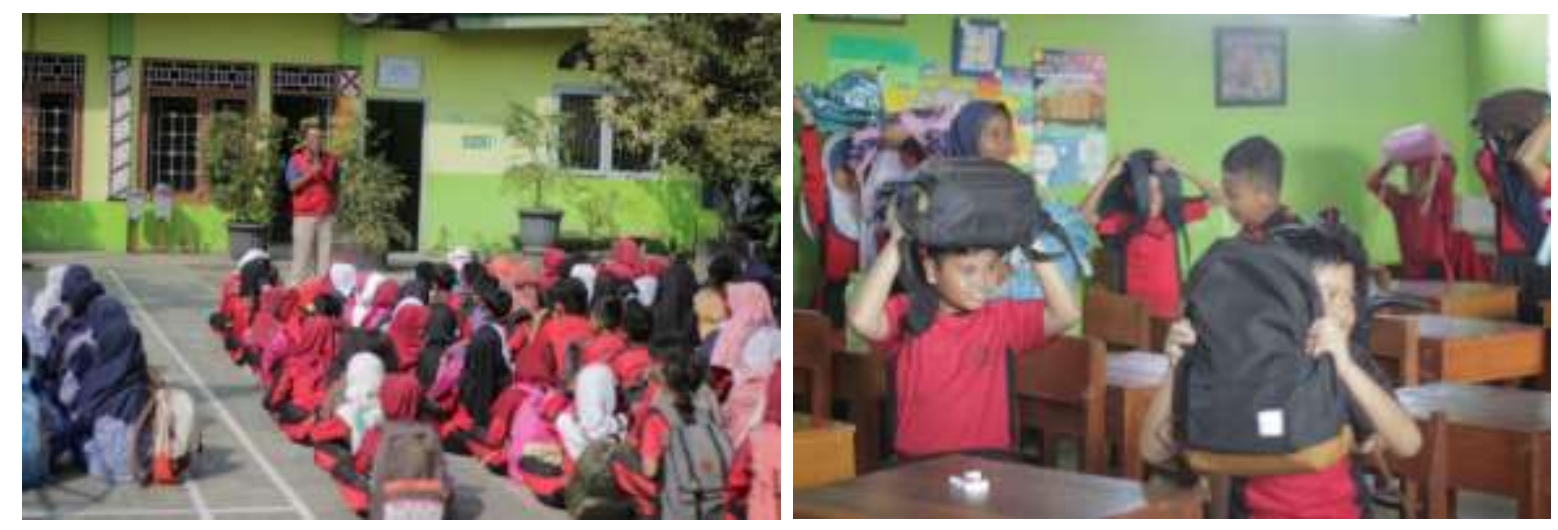

Gambar 3. Kegiatan Simulasi

\section{Simpulan dan Rekomendasi}

Kegiatan pengabdian masyarakat ini sangat bermanfaat sekali bagi sekolah, guru dan siswa, hal terutama dalam memberi pengalaman dan pengetahuan mengenai mitigasi bencana. Sekolah dasar negeri Bantul Timur merupakan salah satu sekolah yang belum mendapatkan sosialisasi mengenai mitigasi bencana sehingga kegiatan ini snagat berguna sekali. Dari hasil kegiatan pengabdian tersebut didapatkan bahwa guru dan siswa-siswi mengikuti kegiatan dengan sangat antusiasi baik kegiatan dihari pertama maupun kegiatan dihari kedua. Adapun kegiatannya yang pertama dilakukan adalah forum group discussion kepada guru-guru serta penjaga sekolah dan karyawan, dan kegiatan ini diikuti dengan sangat antusias karena bagian dari pengalaman baru bagi guru, penjaga sekolah maupun karyawan. Selanjutnya kegiatan sosialisasi dan simulasi, yang mana dalam kegiatan ini diikuti dengan sangat antusias oleh siswa dan guru, sehingga kegaitan ini sangat bermanfaat bagi siswa dan guru dalam menyelamatkan diri ketika terjadi bencana. Kegiatan ini dianggap sebagai langkah awal bagi pihak sekolah untuk menjadikan Sekolah Dasar Negeri Bantul Timur sebagai sekolah aman bencana di Kabupaten Bantul. Saran untuk menjadikan pendidikan dini mitigasi bencana lebih efektif maka kedepan Sekolah Dasar Negeri Bantul Timur bisa direkomendasikan untuk menjadi Sekolah 
Siaga Bencana. Sehingga dengan dijadikannya sekolah siaga bencana tersebut guru dan siswa harus memhamaii apa yang harus dilakukan ketika terjadi bencana, serta harus dilengkapi dnegan beberapa standar operational prosedur (SOP).

\section{Acknowledgements}

Dengan tertulisnya artikel ini saya berterima kasih banyak kepada LP3M Universitas Muhammadiyah Yogyakararta yang telah banyak membantu dan mensuport untuk kelancaran kegiatan pengabdian masyarakat ini. Selain itu saya juga ucapkan terima kasih banyak kepada Sekolah Dasar Negeri Bantul Timur yang telah bersedia menjadi salah satu mitra kami dalam pelaksanaan pengabdian masyarakat, kami ucapkan terima kasih juga kepada BPBD Kabupaten Bantul yang banyak membantu kami dalam pelaksanaan pengabdian terutama dalam hal pendidikan usia dini mitigasi bencana bagi anak-anak Sekolah Dasar. Tidak lupa juga kami ucapakan terimakasih banyak kepada tim teknis pengabdian masyarakat sehingga kegiatan ini bisa berjalan lancar.

\section{Daftar Pustaka}

Nirmalawati. (2011). Pembentukan Konsep Diri Pada Siswa Pendidikan Dasar Dalam Memahami Mitigasi Bencana. Jurnal SMARTek. Vol. 9 No. 1. Februari.

Suarmika, Putu Eka dan Erdi Guna Utama. (2017). Pendidikan Mitigasi Bencana Di Sekolah Dasar (Sebuah Kajian Analisis Etnopedagogi). Jurnal Pendidikan Dasar Indonesia. Volum 2 Nomor 2 bulan September.

https://www.republika.co.id/berita/nasional/news-analysis/19/01/02/pkojtl430-mencarimodel-yang-tepat-untuk-pendidikan-mitigasi-bencana. Diakses pada tanggal 13 Agustus 2019 Pukul 20.00 WIB.

https://www.kompasiana.com/altip/5bb1d028ab12ae5c63656647/pentingnya-penerapanpendidikan-mitigasi-bencana-di-sekolah?page=all. Diakses pada tanggal 13 Agustus 2019 Pukul 21.00 WIB. 